\title{
Jetzt noch schnell anmelden: Abdominelle Bildgebung \& Urogenitalsystem bei Kindern und Jugendlichen
}

Seien Sie bei der hybriden Kinderradiologischen Fortbildung 2022 der AG Pädiatrische Radiologie dabei (Präsenz in Hannover + Live Stream via zoom). Am 11. und 12. März 2022 erwarten Sie unter der wissenschaftlichen Leitung von Prof. Dr. Diane Miriam Renz und Dr. Jürgen Weidemann insgesamt sechs lehrreiche Sessions. Mehr Informationen erhalten Sie unter www.kinder-radiologie.org.

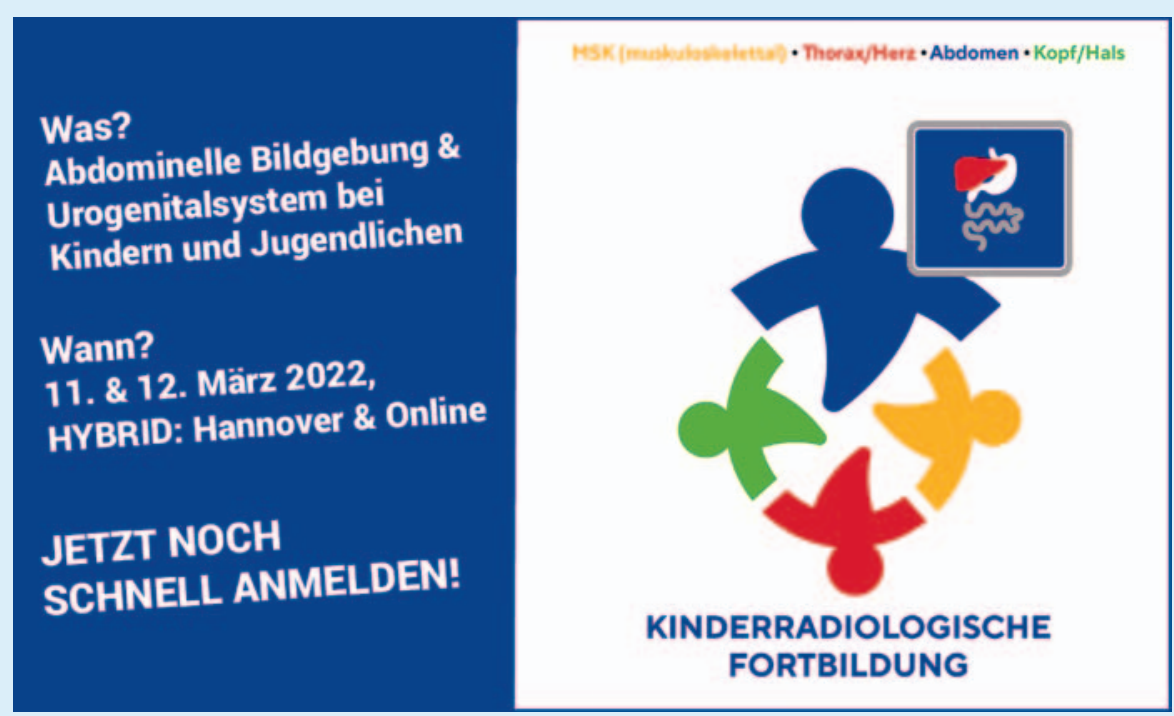

